
FIT(PATOLOGI
Volume 10, Nomor 3, Juni 2014
I N DONESIA
ISSN: 0215-7950
Halaman 81-86
DOI: $10.14692 / \mathrm{jfi} .10 .3 .81$

\title{
Efisiensi Tular Benih Squash mosaic virus pada Cucurbitaceae
}

\author{
Seed Transmission Efficiency of \\ Squash mosaic virus on Cucurbitaceae \\ Susanti Mugi Lestari, Endang Nurhayati* \\ Institut Pertanian Bogor, Bogor 16680
}

\begin{abstract}
ABSTRAK
Infeksi virus pada tanaman Cucurbitaceae dapat menyebabkan kegagalan panen dan kerugian ekonomi yang tinggi. Salah satu virus utama yang terbawa benih tanaman Cucurbitaceae ialah Squash mosaic virus (SqMV). Penelitian ini bertujuan mendeteksi keberadaan beberapa virus pada tanaman Cucurbitaceae dan menguji efisiensi tular benih SqMV. Deteksi Cucumber mosaic virus (CMV), SqMV, Watermelon mosaic virus-2 (WMV-2), Zucchini yellow mosaic virus (ZYMV), dan Tobacco ringspot virus (TRSV) pada sampel daun dan benih Cucurbitaceae dilakukan dengan menggunakan metode Indirect-ELISA. Infeksi CMV, SqMV, dan ZYMV terdeteksi pada sampel daun dari lapangan. Persentase SqMV tertular melalui benih komersial oyong, semangka, zucchini, kabocha, mentimun, dan melon berturut-turut adalah 13, 13, 33, 73, 100, dan 100\%. Infeksi ZYMV hanya ditemukan pada benih oyong dan zucchini berturut-turut sebanyak 13\% dan 27\%. Infeksi SqMV terbawa benih keturunan kedua (F2) ditemukan pada biji mentimun, oyong, dan melon berturut-turut 93, 100, dan 100\% benih. Status SqMV sebagai organisme pengganggu tumbuhan karantina A1 perlu ditinjau kembali karena SqMV telah ditemukan di Jawa Barat.
\end{abstract}

Kata kunci: Cucumber mosaic virus, indirect-ELISA, Zucchini yellow mosaic virus

\begin{abstract}
Infection of viruses on Cucurbitaceae may cause high yield and economic losses. Squash mosaic virus is a seed borne virus and among the most important virus infecting Cucurbitaceae. The aims of these research was to detect infection of several viruses on Cucurbitaceae and to examine seed transmission efficiency of SqMV. Detection of Cucumber mosaic virus (CMV), Squash mosaic virus (SqMV), Watermelon mosaic virus-2 (WMV-2), Zucchini yellow mosaic virus (ZYMV), and Tobacco ringspot virus (TRSV) from field samples and seeds was conducted using Indirect-ELISA method. Infection of CMV, SqMV and ZYMV was detected from field samples. Seed transmission of SqMV on commercial seeds of bottle gourd, watermelon, zucchini, cabocha, cucumber, and melon was 13, 13, 33, 73,100 , and $100 \%$, respectively. Seed transmission of ZYMV was only occurred on bottle gourd and zucchini, i.e. $13.3 \%$ and $26.67 \%$, respectively. Infection of SqMV through F2 seed was determined from cucumber, bottle gourd, and melon, i.e. 93, 100, and 100\%, respectively. Therefore, the status of SqMV as quarantine pest should be evaluated since SqMV was already found in West Java.
\end{abstract}

Key words: Cucumber mosaic virus, indirect-ELISA, Zucchini yellow mosaic virus

*Alamat penulis korespondensi: Departemen Proteksi Tanaman, Fakultas Pertanian, Institut Pertanian Bogor Kampus Darmaga, Jalan Kamper, Bogor 16680

Tel: 0251- 8629364, Faks: 0251-8629362, Surel: end_nur@yahoo.com.au 


\section{PENDAHULUAN}

Infeksi virus pada tanaman Cucurbitaceae merupakan salah satu kendala produksi yang sangat penting. Sekitar 32 virus berbeda dilaporkan dapat menginfeksi tanaman Cucurbitaceae di dunia, di antaranya Cucumber mosaic virus (CMV), Papaya ringspot virus (PRSV), Squash mosaic virus (SqMV), Watermelon mosaic virus (WMV), Zucchini yellow mosaic virus (ZYMV) (Coutts dan Jones 2005), Tobacco ringspot virus (TRSV) (Jossey dan Babadoost 2008), Cucumber green mottle mosaic virus (CGMMV), dan Melon necrotic spot virus (MNSV) (Ali et al. 2012). SqMV diketahui bersifat tular benih (Sevik dan Toksoz 2008), selain dapat ditularkan secara mekanis dan melalui serangga sehingga memiliki potensi untuk memencar secara meluas ke seluruh dunia. Benih yang terinfestasi oleh virus dapat menjadi sumber inokulum primer di pertanaman, dan infeksi virus pada benih dapat menyebabkan perubahan rasa dan kandungan nutrisi, daya kecambah benih, bobot buah, dan jumlah produksi buah.

Menurut Badan Karantina Pertanian Departemen Pertanian RI (Kepmentan 2006) SqMV dikategorikan sebagai organisme pengganggu tumbuhan karantina (OPTK) kategori A1, jadi virus ini belum terdapat di wilayah Negara Republik Indonesia. Kenyataannya, Aulia (2004) berhasil mendeteksi SqMV di Bogor pada beberapa tanaman Cucurbitaceae baik secara tunggal maupun bersamaan dengan virus lainnya. Tanaman mentimun terinfeksi oleh SqMV dan CMV, oyong oleh SqMV, ZYMV, dan TRSV, dan labu siam oleh SqMV dan ZYMV. Status SqMV di Indonesia masih perlu dipastikan berkaitan dengan semakin banyaknya benih tanaman dari luar negeri.

Penelitian dilakukan untuk mendeteksi keberadaan beberapa virus pada beberapa jenis tanaman Cucurbitaceae dan menguji potensi SqMV terbawa benih.

\section{BAHAN DAN METODE}

\section{Lokasi Pengambilan Sampel Tanaman Sakit}

Sampel tanaman sakit terdiri atas beberapa jenis tanaman Cucurbitaceae yang berasal dari lokasi yang berbeda. Mentimun (Cucumis sativus) diambil dari Desa Situ Gede, Kecamatan Darmaga, Kabupaten Bogor; oyong (Luffa acutangula) dari Desa Petir Cibereum, Kecamatan Darmaga, Kabupaten Bogor; melon (Cucumis melo) dari kebun Taman Buah Mekarsari, Desa Mekarsari, Kecamatan Cileungsi, Kabupaten Bogor; zucchini (Cucurbita pepo) dan labu siam (Sechium edule) dari kebun percobaan Balai Penelitian Tanaman Sayuran, Desa Cikole, Kecamatan Lembang, Kabupaten Bandung Barat; serta kabocha (Cucurbita maxima) dari Desa Cibedug, Kecamatan Lembang, Kabupaten Bandung Barat.

\section{Deteksi Virus dengan Indirect Enzyme- Linked Immunosorbent Assay (I-ELISA)}

Deteksi virus dilakukan menggunakan metode I-ELISA menurut Dijkstra dan de Jager (1998). Antiserum yang digunakan, ialah CMV (1:200), SqMV (1:200), TRSV (1:1000), WMV (1:200), dan ZYMV (1:1000) (Agdia, USA).

\section{Pengujian Virus Tular Benih}

Benih yang digunakan untuk pengujian, yaitu benih mentimun, oyong, melon, semangka, zucchini, dan kabocha yang berasal dari benih-benih komersial yang umum digunakan oleh para petani. Jumlah benih yang diuji untuk masing-masing jenis tanaman ialah 15 benih. Benih tersebut ditumbuhkan pada medium tanah steril yang mengandung kompos dengan perbandingan 1:1. Setelah kemunculan daun pertama uji dilakukan untuk mendeteksi keberadaan SqMV dan ZYMV dengan antiserum spesifik menggunakan metode I-ELISA.

Tanaman muda yang positif terinfeksi oleh SqMV atau ZYMV dipelihara sampai 
menghasilkan buah dan diamati gejala yang muncul selama pertumbuhan tanaman. Biji diekstrak dari buah dari masing-masing tanaman, kemudian ditanam sampai muncul daun pertama dan selanjutnya dilakukan deteksi SqMVdan ZYMV dengan antiserum spesifik menggunakan metode I-ELISA.

\section{HASIL}

\section{Gejala Infeksi Virus pada Tanaman Cucurbitaceae}

Gejala infeksi virus pada tanaman mentimun memperlihatkan mosaik hijaukuning dengan warna hijau tua lebih banyak berada di sekitar tulang daun (vein banding), daun menjadi kaku dan berkerut serta mengalami penyempitan ukuran daun, dan tanaman menjadi kerdil. Tanaman oyong yang terinfeksi virus menunjukkan gejala mosaik hijau-kuning, terjadi penyempitan ukuran daun, dan kerdil. Gejala infeksi virus pada tanaman melon berupa mosaik hijau tua-hijau muda pada daun, klorosis, melepuh, keriting, kaku, penyempitan ukuran daun, tepi daun mengalami perubahan bentuk menjadi lebih bergerigi, dan kerdil. Pada tanaman zucchini, gejala mosaik tidak terlihat jelas, tetapi daun menjadi kaku, mengalami sedikit pelepuhan dan perubahan bentuk walaupun ukuran daun tetap normal. Pada tanaman kabocha terlihat gejala mosaik ringan, ukuran dan bentuk daun tidak mengalami perubahan tetapi daun kabocha mengalami sedikit perubahan bentuk. Pada tanaman labu siam terdapat gejala klorosis pada daun, perubahan bentuk dan pengurangan ukuran daun, tetapi tidak terjadi mosaik.

\section{Deteksi Virus pada Tanaman \\ Cucurbitaceae dan Benih}

Virus-virus pada tanaman Cucurbitaceae yang berhasil dideteksi ialah CMV, SqMV, dan ZYMV (Tabel 1). SqMV merupakan virus yang paling banyak ditemukan, yaitu pada tanaman mentimun, zucchini, kabocha, dan labu siam; bahkan pada tanaman kabocha, semua sampel yang diuji terinfeksi SqMV.

Keberadaan SqMV serta ZYMV pada benih Cucurbitaceae komersial berturut-turut berkisar antara 13\% dan 100\% serta $0 \%$ dan $27 \%$. Infeksi SqMV dideteksi pada semua jenis benih dan mencapai $100 \%$ pada benih mentimun dan melon, sedangkan infeksi ZYMV hanya dideteksi dari benih oyong dan zucchini (Tabel 2).

\section{Infeksi SqMV Asal Benih pada Beberapa Tanaman Cucurbitaceae di Rumah Kaca}

Gejala yang terlihat pada tanaman Cucurbitaceae yang berasal dari benih terinfeksi SqMV bervariasi dari ringan (oyong dan semangka) hingga berat (kabocha). Gejala ringan umumnya berupa sedikit pengerutan pada tulang daun mosaik ringan. Gejala paling berat terlihat pada kabocha, yaitu daun mengalami mosaik kuning-hijau, vein banding, pemucatan tulang daun, daun menjadi kaku, keriting, mengalami perubahan bentuk daun, ukuran daun lebih sempit, daun pada pucuk yang baru tumbuh menangkup ke atas seperti mangkuk tetapi daun yang sudah tua

Tabel 1 Infeksi beberapa virus pada tanaman Cucurbitaceae di lapangan berdasarkan deteksi menggunakan antiserum spesifik

\begin{tabular}{lccccc}
\hline \multirow{2}{*}{ Tanaman } & \multicolumn{3}{c}{ Antiserum } \\
& CMV & SqMV & TRSV & WMV-2 & ZYMV \\
\hline Mentimun & $0 / 7 *$ & $3 / 7$ & $0 / 7$ & $0 / 7$ & $0 / 7$ \\
Oyong & $0 / 3$ & $0 / 3$ & $0 / 3$ & $0 / 3$ & $0 / 3$ \\
Melon & $1 / 3$ & $0 / 3$ & $0 / 3$ & $0 / 3$ & $0 / 3$ \\
Zucchini & $0 / 2$ & $1 / 2$ & $0 / 2$ & $0 / 2$ & $0 / 2$ \\
Kabocha & $0 / 3$ & $3 / 3$ & $0 / 3$ & $0 / 3$ & $0 / 3$ \\
Labu siam & $0 / 3$ & $1 / 3$ & $0 / 3$ & $0 / 3$ & $1 / 3$ \\
\hline
\end{tabular}

*a/b: a, jumlah sampel bereaksi positif terhadap antiserum; b, jumlah total sampel yang diuji. 
Tabel 2 Infeksi SqMV dan ZYMV pada benih komersial beberapa tanaman Cucurbitaceae

\begin{tabular}{lllll}
\hline Tanaman & \multicolumn{3}{c}{ Persentase benih terinfeksi } \\
& \multicolumn{2}{c}{ SqMV } & \multicolumn{2}{c}{ ZYMV } \\
\hline Mentimun & 100 & $(15 / 15)$ & 0 & $(0 / 15)$ \\
Oyong & 13.3 & $(2 / 15)$ & 13.3 & $(2 / 15)$ \\
Melon & 100 & $(15 / 15)$ & 0 & $(0 / 15)$ \\
Zucchini & 33.3 & $(5 / 15)$ & 26.67 & $(4 / 15)$ \\
Kabocha & 73.3 & $(11 / 15)$ & 0 & $(0 / 15)$ \\
Semangka & 13.3 & $(2 / 15)$ & 0 & $(0 / 15)$ \\
\hline *a/b: a, jumlah sampel bereaksi positif terhadap \\
anti serum; b, jumlah total sampel yang diuji.
\end{tabular}

menangkup ke bawah dan terjadi pertumbuhan cabang vegetatif yang berlebihan (Gambar 1a dan b).

Gejala infeksi virus tidak hanya terlihat pada bagian daun, tetapi juga tampak pada buah (Gambar 1c, d, dan f). Buah mentimun menunjukkan gejala berupa penggentingan pada pangkal buah dan bentuk buah yang tidak teratur. Gejala pada oyong ialah perubahan bentuk alur-alur yang tidak teratur, walaupun sebagian besar buah tidak menunjukkan gejala. Gejala pada buah melon ialah perubahan bentuk buah, corak permukaan kulit buah yang tidak rata atau tidak bercorak. Tanaman kabocha, zucchini dan semangka dapat menghasilkan bunga tetapi tidak membentuk buah sehingga gejala pada buah tidak dapat diamati.

Infeksi SqMV pada benih mentimun, oyong, dan melon yang berasal dari tanaman terinfeksi dapat dideteksi dengan I-ELISA dengan persentase infeksi berkisar antara 93\% dan 100\% (Tabel 3). Persentase infeksi SqMV pada benih turunan kedua (F2) lebih tinggi dibandingkan dengan infeksi pada benih F1, terutama terjadi pada benih oyong. Persentase infeksi SqMV pada benih oyong meningkat dari $13 \%$ pada benih F1 menjadi $100 \%$ pada benih F2.

\section{PEMBAHASAN}

Gejala infeksi virus pada tanaman Cucurbitaceae yang ditemukan di lapangan bervariasi dari ringan hingga berat. Beberapa faktor yang mempengaruhi variasi gejala

Tabel 3 Infeksi SqMV pada benih mentimun, melon dan oyong asal tanaman terinfeksi

\begin{tabular}{lrc}
\hline Tanaman & \multicolumn{2}{c}{ Persentase benih terinfeksi } \\
\hline Mentimun & 93 & $(14 / 15)^{*}$ \\
Oyong & 100 & $(10 / 10)$ \\
Melon & 100 & $(15 / 15)$ \\
\hline
\end{tabular}

*a/b: a, jumlah sampel bereaksi positif terhadap anti serum; b, jumlah total sampel yang diuji.

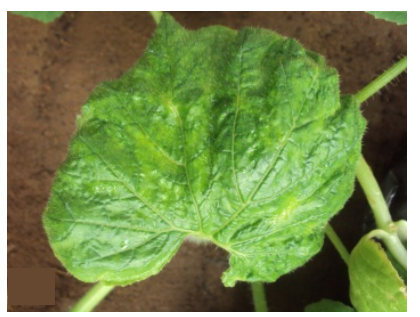

a

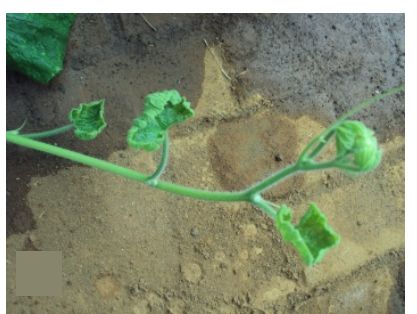

$\mathrm{b}$

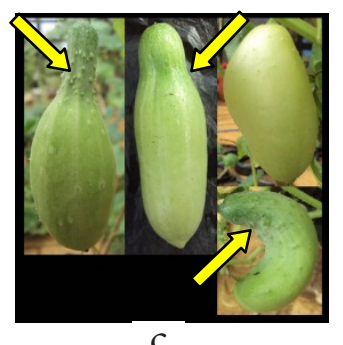

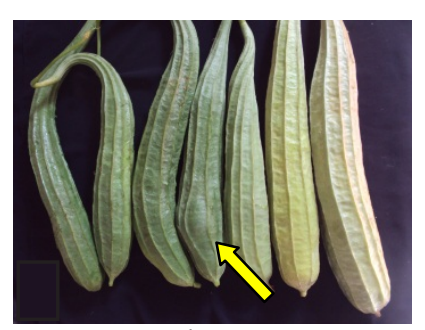

d

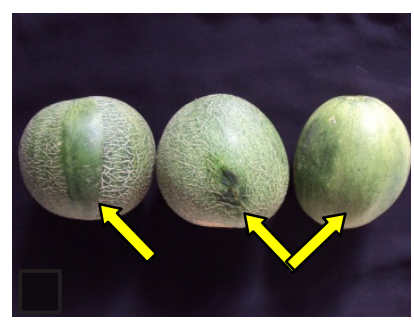

$\mathrm{e}$

Gambar 1 Gejala pada tanaman Cucurbitaceae yang berasal dari benih terinfeksi SqMV. a, mosaik dan perubahan bentuk pada daun kabocha; b, perubahan bentuk daun pada pucuk tanaman kabocha; c, perubahan bentuk buah mentimun; d, perubahan bentuk alur oyong; e, perubahan bentuk buah melon. 
tersebut ialah jenis dan virulensi virus, jenis tanaman inang, kondisi lingkungan tumbuh tanaman dan lokasi terjadinya penyakit tersebut. Jossey dan Babadoost (2008) melaporkan bahwa 6 virus utama yang menginfeksi Cucurbitaceae ialah CMV, SqMV, ZYMV, WMV, PRSV, dan TRSV. Hasil yang sama dilaporkan oleh Aulia (2004) yang berhasil mendeteksi CMV, PRSV-W, SqMV, TRSV, WMV-2, dan ZYMV dari tanaman Cucurbitaceae di Bogor dengan persentase infeksi SqMV yang paling banyak ditemukan.

Ali et al. (2012) melaporkan persentase tanaman Cucurbitaceae yang terinfeksi SqMV hanya sebesar 3.8\%. Sementara itu, Sevik dan Toksoz (2008) melaporkan bahwa infeksi SqMV pada labu (Cucurbita moschata dan $C$. maxima) sebanyak $21.11 \%$ dan pada zucchini sebanyak 20\%, sedangkan Dikova dan Hristova (2002) menyatakan bahwa SqMV yang terbawa benih pada benih Cucurbitaceae mencapai 91\%.

Alvarez dan Campbell (1978) menjelaskan bahwa keberadaan SqMV pada benih tidak hanya terdapat pada embrio, tetapi juga pada protoplasma kotiledon, embrio, jaringan palisade, dan jaringan mesofil. Persentase virus tertular melalui benih ditentukan oleh persentase embrio terinfeksi, selanjutnya embrio yang terinfeksi selalu menghasilkan benih terinfeksi. Virus yang ditularkan melalui benih ini sangat berpotensi dalam penyebaran penyakit karena benih yang terinfestasi virus dapat menjadi sumber inokulum primer. Selain itu, infeksi virus sejak tanaman masih muda dapat menyebabkan gejala yang berat (Coutts 2006), misalnya tanaman menjadi kerdil, tanaman dapat mengalami rebah dan kematian pada masa pesemaian, dapat tidak berbuah bila tanaman terinfeksi pada masa pembungaan, dan mengalami perubahan bentuk buah.

Keberadaan SqMV pada tanaman dan benih Cucurbitaceae di Bogor dan Bandung ini merupakan bukti bahwa SqMV telah berada di Indonesia. Peningkatan infeksi SqMV di Indonesia kemungkinan besar disebabkan oleh adanya benih impor Cucurbitaceae dari negara-negara dengan tingkat kejadian penyakit yang tinggi. Pembuktian yang dilakukan pada penelitian ini dan penelitian Aulia (2004) tentang keberadaan SqMV di beberapa tempat di Jawa Barat dapat menjadi landasan untuk menentukan penurunan status SqMV dari OPTK A1 menjadi OPTK A2, yaitu jenis-jenis organisme pengganggu tumbuhan karantina yang sudah terdapat di dalam wilayah Negara Republik Indonesia, tetapi terbatas pada lokasi atau daerah tertentu (Kepmentan 2006).

\section{DAFTAR PUSTAKA}

Ali A, Mohammad O, Khattab A. 2012. Distribution of viruses infecting cucurbit crops and isolation of potential new viruslike sequences from weeds in Oklahoma. Plant Dis. 96(2):243-248. DOI: http:// dx.doi.org/10.1094/PDIS-05-11-0419.

Alvarez M, Campbell RN. 1978. Transmission and distribution of squash mosaic virus in seeds of cantaloupe. Phytopathol 68:257263. DOI: http://dx.doi.org/10.1094/ Phyto-68-257.

Aulia R. 2004. Inventarisasi dan deteksi virus penyebab mosaik pada famili Cucurbitaceae di Kotamadya Bogor, Pasir Muncang dan Cibodas [skripsi]. Bogor (ID): Institut Pertanian Bogor.

Coutts BA, Jones RAC. 2005. Incidence and distribution of viruses infecting cucurbit crops in the Northern Territory and Western Australia [abstrak]. Aus J Agric Res. 56(8):847-858. DOI: http://dx.doi. org/10.1071/AR04311.

Dijkstra J, de Jager CP. 1998. Practical Plant Virology. Protocol and Exercise. Berlin (DE): Springer-Verlag Berlin Heidelberg. DOI: http://dx.doi.org/10.1007/978-3-64272030-7.

Dikova B, Hristova D. 2002. Detection of squash mosaic virus, zucchini yellow mosaic virus and cucumber mosaic virus in cucurbit seeds. Bulg J Agric Sci. 8:201210.

Jossey S, Babadoost M. 2008. Occurrence and distribution of pumpkin and squash 
viruses in Illinois. Plant Dis. 92:61-68. DOI: http://dx.doi.org/10.1094/PDIS-921-0061.

[Kepmentan] Keputusan Menteri Pertanian. 2006. Keputusan Menteri Pertanian Nomor: 38/KPTS/HK.060/1/2006 tentang Jenis-Jenis Organisme Pengganggu Tumbuhan Karantina Golongan I Kategori A1 dan A2, Golongan II Kategori A1 dan
A2, Tanaman Inang, Media Pembawa dan Daerah Sebarnya. Jakarta (ID): Menteri Pertanian.

Sevik MA, Toksoz Y. 2008. Occurrence of Squash mosaic virus (SqMV) infecting pumpkin and squash growing in Samsun, Turkey. J Turk Phytopathol. 37(1-3):1525. 